\title{
NOTES
}

\section{The Irrevocable Proxy and Voting Control of Small Business Corporations}

Voting control of business corporations is prized because, through selection of a majority of directors, it is the power to determine the use of group assets. Since directors are chosen by vote at annual shareholder meetings, those who have the legal right to vote a majority of enfranchised shares retain the potential power of control. In the case of large corporations with widely scattered ownership, factual control, by the availability of the proxy machinery, may reside in a group owning only a small percentage of outstanding voting shares. In more closely held corporations, attempts are made to achieve the same result by divorcing the legal right to vote a majority of shares from ownership through the use of legal devices such as non-voting shares, voting trusts, voting and pooling contracts, and irrevocable proxies. This Note is concerned with the problem of voting control of the closely held, usually small, corporation. Since voting trusts, whereby owners transfer rights to trustees, are now largely legislative creatures, the discussion will be confined to an examination of the irrevocable proxy, and the voting or pooling contract, two relationships whose judicial enforceability is still subject to doubt. Judicial confusion over the validity of these voting agreements is more readily understood in the light of the general theory of the business corporation evolving in a democratic society, and against the background of traditional agency doctrine.

\section{The Structure of Corporate Democracy}

In the early law of business corporations, each shareholder was accorded the same number of votes, regardless of his proportionate share ownership. This was a vestige of the voting rules of the public or municipal corporation, whose charter was a gift of the Crown. The right to vote was a personal trust given the member, and the same political philosophy which assumed that every man had an equal interest in good government, and that the highest governmental wisdom would result from a clash of such individuals, was thought to be applicable to business corporations. ${ }^{1}$ Related to this belief was the doctrine that each shareholder had contracted for the independent advice and judgment of his fellow members at elections. ${ }^{2}$ In the absence of statutory or by-law authority, therefore, proxy voting was not permitted. ${ }^{3}$

With the appearance of general incorporation statutes permitting incorporation almost at will, and without the need for a special legislative act, this philosophy became inapplicable. When voting rights commensurate with proportionate ownership were granted, the individual member was displaced by the dollar investment as the voting unit of the group.

1. Axe, Corporate Proxies, 41 MrCF. L. Rev. 35 (1942) ; Bergerman, Voting Trusts and Non-Voting Stock, 37 YALE L.J. 445, 447 (1928).

2. Rohrlich, Corporate Voting: Majority Control, 7 ST. JoHn's L. Rev. 218, 225 (1933)); Note, 3 U. OF CHI. L. REv. 640, 642 (1936).

3. Commonwealth ext rel. Verree v. Bringhurst, $103 \mathrm{~Pa} .134$ (1883); see Philips v. Wickham, 1 Paige 590, 597 (N.Y. 1829). 
Shareholders did not have to be present at meetings in order to exercise their judgment upon the deliberations of their associates, and, if absent, could vote by proxy. Finally, free transferability of shares made a fiction of the shareholder's contract for the judgment of his associates, since, unlike a business partner, he had no control over the personnel of the membership.

Theory of Over-all Corporate Welfare.-These steps in the modern evolution of the business corporation occurred in the process of securing to private owners the legislatively implemented benefits of their property. The very structure of the business corporation-one dollar, one vote, to create representative management-initially gave owners the function of dispensing the corporate patronage and distributing the corporate earnings as their interests dictated. Implicit was the fundamental assumption that the corporation's business policies would be guided so as to maximize profits: the self-interest of ownership was to provide impetus and leadership. This same self-interest of the majority of owners, which would be directed toward making the corporate affairs prosper, would work to the advantage of the minority. ${ }^{4}$ If that whip were not sufficient, the courts were prepared to prevent a majority from profiting at the expense of the corporation, $i . e_{\text {. }}$, at the expense of the minority.

The theory of over-all corporate welfare was most directly expressed as a policy against the separation of voting rights from share ownership. By depriving himself of the right to vote, and by concentrating voting power in another, it was thought that the shagreholder exposed minority owners to dangers of improper management motivation. ${ }^{5}$ The general corporate welfare was also thought to be imperilled by the sale of votes. This policy retains full vigor today. Besides the sanction of ordinary liability for management profit at corporate expense, a prophylactic rule prohibiting use of a purchased vote has been accepted. ${ }^{6}$ Certainly the temptation to the vote-buyer to recoup his expense from the corporate treasury is too great to risk. Similarly, a vote may not be purchased by the promise of a salaried job with the corporation, since each director has a duty to remain free, after election, to exercise independent judgment for the welfare of the corporation. ${ }^{7}$

With the acceptance of non-voting shares and voting trusts, however, together with the frequently attempted use of irrevocable proxies and voting contracts, the argument has been made that the traditional policy against separation of ownership from voting rights is moribund. ${ }^{8}$ The widespread use of ordinary proxies has also been thought by some to point toward the same inference. ${ }^{9}$ In order to assess the current situation informedly, an examination of the development of agency doctrine and its application to corporate voting is indispensable.

4. See Morel v. Hoge, 130 Ga. 625, 632, 61 S.E. 487, 490 (1908) ; Luthy v. Ream, 270 Iil. 170. 179, 110 N.E. 373. 376 (1915) ; Cone v. Russell \& Mason, 48 N.J. Eq. 208, 212, 21 At1. 847, 849 (Ch. 1891).

5. For a lucid analysis of this theory, see Cone v. Russell \& Mason, 48 N.J. Eq. 208, 212, 21 At1. 847, 849 (Ch. 1891).

6. Macht v. Merchants' Mortgage Co., 22 Del. Ch. 74, 194 Atl. 19 (Ch. 1937); Laughlin v. Johnson, 230 Ill. App. 25 (1923) ; Palmbaum v. Magulsky, 217 Mass. 306, 104 N.E. 746 (1914).

7. Williams v. Fredericks, 187 La. 987, 175 So. 642 (1937) ; McQuade v. Stoneham, 263 N.Y. 323, 189 N.E. 234 (1934). Where the thing of value given for the vote is a salaried job, the contract violates both principles.

8. See notes $62-65$ infra and text.

9. Rohrlich, Law and Practise in Corporate Control 44 (1933). The argument ignores the fact that owners retain the right to change their minds. 


\section{Agency Powers and Powers "Coupled With an Interest"}

The Ordinary Proxy. - The fiduciary obligation of an agent to act for the interests of his principal and in accordance with his instructions applies in haec verba to the ordinary proxy. It is merely an authority to vote the absent owner's shares, given presumably out of the self-interest of ownership. The shareholder may revoke the proxy by attending the election and voting in person; ${ }^{10}$ he may revoke it by executing a subsequent proxy; ${ }^{\text {i1 }}$ he retains all the powers of the ordinary principal, except as agency rules need to be modified by the practical necessities of corporate balloting. Furthermore, the fiduciary obligation of an agent to act for the interests of his principal renders invalid a vote cast contrary to his interest or instructions. ${ }^{12}$ Even when a majority of owners give uninstructed or discretionary proxies, they retain at all times the pozver to vote themselves for their self-interest. ${ }^{13}$ To say, therefore, that judicial and legislative recognition of proxy voting evidences an abandonment of the policy against allowing the separation of ownership from voting rights, is to be seriously superficial.

Powers "Coupled With an Interest."-Agency doctrine provides that ordinary powers of attorney including the proxy power, are revocable by act of the principal and terminable by his death.14 In an agency relationship, even when a contract of employment exists by which the agent is to reimburse himself out of the proceeds of his exercise of authority, the principal retains the power to revoke the authority. By doing so, however, he incurs a liability to the agent for breach of the contract of employment. Nor can the parties change the legal relationship by agreeing that the authority of the agent is to be irrevocable. ${ }^{15}$ The agent is doing business for another, and needs the principal's consent before he may act validly. The law does not permit him to continue against his principal's will merely because he wants to earn compensation, and has a contract to perform services. He is relegated to an action at law for damages. To allow him to continue would be analogous to granting him specific performance where his remedy at law is adequate.

The situation is strikingly different when the agent makes advances to the principal, or incurs personal obligations for his benefit and at his request, in reliance upon the power of attorney as security for repayment. Here the "agent" has been held entitled to a property right in the power, so that it is not revocable by the principal so long as the security need exists. Such a power is termed "proprietary," since it exists independently of the principal's consent. ${ }^{18}$ It is no longer a mere power of at-

10. Blanche v. Central Ieather Co., 78 N.J. Eq. 484, 81 Atl. 571 (Ch. 1911); In re Schwartz \& Gray, 77 N.J.L. 415, 72 Atl. 70 (1909) ; Commonwealth ex rel. Langdon v. Patterson, $158 \mathrm{~Pa} .476,27$ Atl. 98 (1893).

11. Pope v. Whitridge, $110 \mathrm{Md}$. 468, 73 Atl. 281 (1909).

12. McClean v. Bradley, 299 Fed. 379 (6th Cir. 1924); Lowman v. Harvey Pierce Co., 276 Pa. 382, 120 Atl. 404 (1923).

13. A general proxy merely signifies that the agent shall use his own judgment in exercising the privilege.

14. See, generally, 5 Fletcher, Cyclopedia of Corporatrons $\$ 2062$ (perm. ed. 1933) ; 1 Mechem, Agency $\$ \$ 561$ ff., 651 ff. (2d ed. 1914); Stefren, Cases on AgENCY 40 (1933); Lowndes, Powers Coupled With an Interest, 12 HARv. L. REv. 262 (1898) : Seavey, Termination by Death of Proprietary Powers of Attorney, 31 YALE L.J. 283 (1922) ; Note, 64 A.L.R. 380 (1929).

15. 1 MeCheM, AGENCX $\$ 566$ (2d ed. 1914).

16. For the distinction between agency and proprietary powers, see $i d$. at $\S 561$. 
torney. The "agent" now has a legally protected interest, not merely a right to compensation for services rendered which he may exact from the proceeds, but a right to execute the power conferred. ${ }^{17}$

In the celebrated case of Hunt $v$. Rousmanier's Adm'rs, ${ }^{18}$ Chief Justice Marshall introduced the term, "coupled with an interest," into the American law of powers. There he ruled that a power to sell ships, given to a creditor in lieu of mortgage, and with its exercise conditioned upon default of the debtor, was terminated by the death of the debtor (the power-giver), although it was conceded to be irrevocable during his life. Marshall made this distinction apparently because he was dismayed at the idea of executing a conveyance of property in the name of a dead man. ${ }^{19}$ $\mathrm{He}$ expressed his decision by saying that the power was not "coupled with an interest" in the ships, by which he meant, apparently, a legal estate in the ships. The decision has retained validity only with regard to powers over real property; the distinction between termination and revocation is said to have been supported by not even a scintilla of authority. ${ }^{20}$ But the expression, "coupled with an interest," acquired a life of its own. It has since run through cases on revocation as well as termination, ${ }^{21}$ personalty and choses in action as well as realty, ${ }^{22}$ and has caused serious confusion as to its real meaning. ${ }^{23}$ Nowhere else is the power of the pat formula to mask thought better displayed. When the courts came up against the irrevocable proxy and the voting contract, some seized upon the phrase to supply authority for a new departure from sound corporation law.

\section{IRREVOCABLE Proxies}

The irrevocable proxy is an enforceable power given by an owner to exercise his voting rights independently of his future consent. He may accomplish the same result through a voting or pooling contract, or by means of a voting trust. In each instance, some courts have held that the agreements may not be upheld unless the power-holder has a requisite "interest." 24 Sometimes statutes governing the duration of a proxy use

17. Compare American Loan \& Trust Co. v. Billings, 58 Minn. 187, 59 N.W. 998 (1894) (power given to $B$ to sell property and pay proceeds to $C$ in payment of a debt owed $C$ held not revocable by $A$ when executed and accepted as security for such debt) werith Coburn v. Davis, 201 Iowa 1253, 207 N.W. 586 (1926) (power revocable, the agent's advance not having been given in reliance on the power); accord, Arcweld Mfg. Co. v. Burney, 12 Wash. 2d 212, 121 P.2d 350 (1942). Something more than a valuable consideration is essential, for a bare power may be upon such consideration. Paying for a newspaper route does not make the appointment irrevocable. Staroske v. Pulitzer Publ. Co., 235 Mo. 67, 138 S.W. 36 (1911).

18. 8 Wheat. 173 (U.S. 1823).

19. Seavey, Termination by Death of Proprietary Powers of Attorney, 31 YALE L.J. 283, 288 (1922).

20. $I d$. at 288 .

21. Id. at 289 n. 26.

22. Id. at 297.

23. Ibid. A recognized legal estate has always been sufficient. Benneson v. Savage, 131 I11. 352,22 N.E. 838 (1889); Durbrow v. Eppens, 65 N.J.L. 10, 46 At1. 582 (Sup. Ct. 1900).

24. Boyer v. Nesbitt. 227 Pa. 398, 76 Atl. 103 (1910) (voting trusts). Two states have provisions that voting trusts shall not be made irrevocable for more than ten years unless the rights are "coupled with an interest" in the shares. Under certain circumstances the rights are deemed to be so coupled. KAN. GEN. STAT. ANN. \$17-3307 (Corrick, Supp. 1945); OHIo CoDE ANN. \$ 8623-34 (Throckmorton, 1940). Note, 71 A.L.R. 1289 (1931) (voting agreements). 
the same test.25 An important elaboration made by some of the cases is the requirement that the interest exist in the shares themselves, not merely in the right to vote. ${ }^{26}$ The resemblance of this statement to the rule that the "agent" must have an interest in the power itself, and not merely an interest in the proceeds (a right to compensation) for the power to be irrevocable, points to the conclusion that even if execution of a proxy be considered a service for which compensation is contemplated, a mere statement that the proxy is irrevocable will not be binding. As a practical matter, of course, a contract for compensation would rarely accompany the authority to vote, since normally it is given to one who welcomes the opportunity to exercise it, and no "services" for the owner are contemplated.

Testing the "Interest."-Since all courts use the formula that a power must be "coupled with an interest" in order to be irrevocable, it is appropriate to analyze the leading proxy cases in terms of the real "interest" of the power-holder, who is attempting to enforce the agreement. In the Hunt case, Marshall had used the phrase to denote a legal estate in the property upon which the power could act. He was concerned, however, with the narrow question of the terminability, by the death of the power-giver, of a power which was conceded to be irrevocable. Clearly, therefore, the requirement of a legal estate can have no application to problems of revocability.

Brought over into the proxy cases, "interest" should mean only that the power-holder has a genuine need for security, arising out of the same kind of transaction as will make a power proprietary, in the traditional sense. But here the analogy breaks down. In a principal-agent relationship, where the agent advances money to the principal, and secures thereby a proprietary power-one exercisable independently of the principal's consent-the affairs of consenting parties only are involved. In the corporate proxy cases, however, other shareholders have rights which should be considered. The test of the "interest," then may be the presence of a security need which can be asserted harmoniously with the profit motives of ownership.

Financial Commitment to the Corporation.-Such a security need, giving rise to a valid interest, is present when the proxy-holder has made a financial commitment to the corporation, in order to increase its welfare. In Mobile \& Ohio Ry. v. Nicholas, ${ }^{27}$ for example, creditors of an insolvent corporation, in the hands of a receiver, agreed to relinquish decrees of foreclosure and orders of sale, and to allow the corporation to function anew, on condition that irrevocable proxies be given to trustees, for the life of the debts. A shareholder's attempt to enjoin the trustees from voting was unsuccessfu1. ${ }^{28}$ Clearly, the self-interest of the creditors to recover their loans ran parallel to the purpose of ownership to secure the greatest amount of revenue from the operations of the corporation.

25. CAL. CoRp. Code $§ 2228$ (Deering, 1948) ; PA. Stat. ANn., tit. 15, §2852-504 (Purdon, Supp. 1948).

26. In re Public Industrials Corp., 19 Del. Ch. 398, 409, sub nom. In re Chilson, 168 Atl. 82, 85 (Ch. 1933).

27. 98 Ala. 92,12 So. 722 (1893).

28. Accord, Craig v. Bessie Furnace Co., 19 Ohio N.P. Rep. (N.S.) 545, 27 Ohio Dec. N.P. 471 (Franklin Co. C.P. 1917); cf. Mackin v. Nicollet Hotel, 10 F.2d 375 (D. Minn. 1926) (voting trust upheld under similar facts before statutory authorization of the device). 
Again, in Chapman v. Bates, ${ }^{29}$ the directors made advances to the corporation, and incurred personal obligations in expanding its facilities, relying upon an agreement by a majority of the shareholders to give them proxies which were to be irrevocable for two years. A single shareholder's bill to revoke the proxies was dismissed. ${ }^{30}$ Having contributed largely in effort and money to increase the earning power of the corporation, the directors might be expected to use the proxies to try to maximize profits.

Where the proxy-holder has been induced to become a substantial shareholder by the promise of voting control, the agreement is generally upheld. In Hey v. Dolphin, ${ }^{31}$ for example, two partners transferred jointly owned patents to a corporation, in exchange for a majority share interest, under an agreement between them that one partner was to exercise the entire power to vote for ten years. An action by the proxy-giving partner to revoke was unsuccessful. 32 Here the proxy-holder had a substantial financial commitment in the corporation; it was reasonable to believe the statement in the agreement that control was vested in him to insure expert management of the business of the corporation.

Although every irrevocable proxy or pooling arrangement which is enforced entails temporary suspension of potential control by a majority of owners, courts which uphold them derogate in these cases from minority rights only to achieve greater flexibility in corporate financing transactions.

These dangers of minority control are practically non-existent in some situations. Where the proxy-holder is, for example, a party to an executory agreement whereby he is obligated to purchase a majority of the shares over a long period of time, his self-interest in enhancing the value of the shares is apparent. ${ }^{33}$

Negligible Interests. - In the search for interests to couple with proxy powers, some courts have completely lost sight of the rational basis of irrevocability, which is probable parallelism of motive between proxy-holder and ownership as a whole. First rights to purchase and options have been asserted as sufficient interest, ${ }^{34}$ although only in Pennsylvania has this been made an express ground for decision. ${ }^{35}$ Again, the possession of

29. 61 N.J. Eq. 658, 47 Atl. 638 (Ct. Err. \& App. 1900).

30. Cf. State ex rel. Breger v. Rauche, 219 Ind. 559, 562, 39 N.E.2d 433, 434 (1942) (right to reimbursement out of proceeds of stock to be sold not jeopardized by cancellation of authority to vote).

31. 92 Hun 230, 36 N.Y. Supp. 627 (Sup. Ct. 1895).

32. But cf. Gilmer's Heirs v. Veatch, 56 Tex. Civ. App. 511, 121 S.W. 545 (1909) (power of attorney to convey given by joint owner of land to another joint owner held not "coupled with an interest").

33. The court upheld a twenty-year irrevocable proxy, given to depositaries to whom the shares had been assigned under an agreement whereby the depositaries were to purchase the shares over the period. Graub v. Blish, 88 Ind. App. 309, 152 N.E. 609,153 N.E. 895 (1926) (dissent); cf. Stoelting Bros. v. Stoelting, 246 Wis. 109, 16 N.W.2d 367 (1944).

34. The following cases involved options or first rights to purchase, but it is difficult to assess their importance to the decision: Ringling Bros.-Barnum \& Bailey Combined Shows v. Ringling, 53 A.2d 441 (Del. Sup. Ct. 1947); Thompson v. Thompson Carnation Co., 279 IIl. 54, 116 N.E. 648 (1917) (voting agreements); State $e x$ rel. Everett Trust \& Saving Bank v. Pacific Waxed Paper Co., 22 Wash.2d 844, 157 P.2d 707 (1945) ; Stoelting Bros. v. Stoelting, 246 Wis. 109, 16 N.W.2d 367 (1944) (proxies).

35. Although it was a voting trust, the court decided it was necessary to find some interest coupled with the power given the voting trustees, and found such interest in a provision of the agreement giving the trustees a first right to purchase, at 
an unliquidated claim against the corporation, for past services, has been considered sufficient interest to validate the retention of voting rights by a promoter who had sold his shares under such an agreement. ${ }^{36}$

In a few cases, the abandonment of the policy against separating voting power from ownership is unmistakable. Carnegie Trust Co. v. Security Life Insurance Co., ${ }^{37}$ for example, involved a twenty-five year voting trust, with full powers in the trustees to vote the shares independently. The court made an obeisance to the concept of powers "coupled with an interest," by finding the requisite interest in the control resulting from the agreement. ${ }^{38}$ Apparently the control provided the interest, and the interest provided the control. ${ }^{39}$

The outermost limit appears to be reached by a recent Washington case, in which two shareholders having a majority between them agreed that the survivor should have an irrevocable proxy to vote the deceased's shares, to be binding upon heirs, successors and legal representatives. ${ }^{40}$ Upholding the agreement against the executor, the court stated that the general rule of revocability of powers was subject to exception only in the case of powers "coupled with an interest," those given as security or necessary to effectuate such security. It found, however, that the "security' . . . is somewhat elastic, and cases . . . disclose that, whenever the purpose to be served by the exercise of the power is to protect or further the interest of the proxy holder, the authority given is regarded as part of a security or something necessary to effectuate such a security." 41 If this language is to be taken seriously, a proxy secured for the purpose of obtaining a permanent sinecure with the corporation is irrevocable. ${ }^{42}$ The reductio ad absurdum makes it plain that the court was actually treating a voting right as a separately transferable property, subject to complete freedom of contract.

Terminability of Irrevocable Proxies.-The Washington case just discussed exemplifies the general disregard of Marshall's distinction between terminability and revocability. Few cases have expressly considered whether an irrevocable corporate proxy is terminated by the death of the power-giver, but in view of the conceptual grounds for the

double par and for the benefit of the remaining parties, stock of anyone who did not want the trust to continue. Boyer v. Nesbitt, $227 \mathrm{~Pa}$. 398, 76 At1. 103 (1910).

A deposit of shares with power to vote is revocable although accompanied by a power of sale. Woodruff v. Dubuque \& S.C. Ry., 30 Fed. 91 (C.C.S.D.N.Y. 1887). Even if the agent assumed obligations for which he claims reimbursement, this right is not jeopardized by cancelling the power to vote. See State ex rel. Breger v. Rusche, 219 Ind. 559, 562, 39 N.E.2d 433, 434 (1942).

36. Ecclestone v. Indialantic, 319 Mich. 248, 29 N.W.2d 679 (1947). Although the theory of the court is not clear, the test used was that separation is justified where there is "a property interest to conserve, and a definite policy in the interest of the corporation to be carried out." Id. at 256,29 N.W.2d at 682 . The test can be traced to a voting trust decision where the trustees had only a first right to purchase the shares. Boyer v. Nesbitt, 227 Pa. 398, 402, 76 Atl. 103, 104 (1910). See text at note 35 sipra.

37. 111 Va. 1, 68 S.E. 412 (1910).

38. Id. at 27, 68 S.E. at 421. Compare, however, note 26 supra and text.

39. This analysis has been approved: Burke, Voting Trusts Currently Observed, 24 Minn. L. Rev. 347, 351 (1940), and disapproved: Ballantine, Voting Trusts, Their Abuses and Regulation, 21 TEx. I. Rev. 139, 168 n. 96 (1942).

40. State ex rel. Everett Trust \& Saving Bank v. Pacific Waxed Paper Co., 22 Wash.2d 844, 157 P.2d 707 (1945).

41. Id. at 851, 157 P.2d at 710 . Emphasis added.

42. Note, 159 A.L.R. 307, 310 (1945). 
distinction, it seems safe to say that a legal estate in the shares will not be required to prevent termination. ${ }^{43}$ An interesting New York case concerned a voting power retained by a reversioner who had transferred the shares to his wife as security for the payment of alimony. Upon his death, it was held that the proxy did not terminate. ${ }^{44}$ The security needs of the legitimate holder of an irrevocable proxy require also that it be non-terminable by death of the parties.

\section{Voting or Pooling Contracts}

Except for the fact that the shareholder casts the vote himself, voting or pooling contracts have the same consequences as irrevocable proxies. ${ }^{45}$ The policies governing their validity, therefore, are identical. Need for consideration to make the contract enforceable must be interpreted in the light of the cases defining the kinds of interests which will make proxies irrevocable.

Since mutual promises are not a sufficient interest to render proxies irrevocable, ${ }^{46}$ it is difficult to perceive how they can validate voting contracts. ${ }^{47}$ Although numerous cases have been cited by authors for the proposition that agreements by shareholders to vote for certain persons as directors to secure the management of the corporation are enforceable unless fraudulent, ${ }^{48}$ close examination suggests that it cannot be sustained unqualifiedly. Even though a remedy at law for damages is not feasible, ${ }^{49}$ no court has in fact given complete relief by compelling specific performance of such contracts, except where the contracting parties owned all the shares. ${ }^{50}$ The statements that such contracts are valid and binding are dicta thrown out in cases where the agreements were voided because they limited the discretion of directors, ${ }^{51}$ or in cases merely holding that the voting provision did not render other provisions unenforceable.52 While

43. Seavey, Termination by Death of Proprietary Powers of Attorney, 31 Yale L.J. 283,290 (1922).

44. If the husband died, the dividends were to be the sole source of alimony payments, and upon the death of the wife the stock was to revert to the husband's estate. Benkard v. Leonard, 231 App. Div. 625, sub nom. In re Schirmer's Estate, 248 N.Y. Supp. 497 (1st Dep't 1931), 41 YaLE L.J. 921 (1932).

45. Contracts between shareholders for election of certain directors must be distinguished from those which seek to bind the judgment of a director in that capacity. The latter are generally unenforceable. Guernsey v. Cook, 120 Mass. 501 (1876); McQuade v. Stoneham, 263 N.Y. 323, 189 N.E. 234 (1934) ; cf. Manson v. Curtis, 223 N.Y. 313, 324, 119 N.E. 559,561 (1918).

46. Johnson v. Spartenburg Co. Fair, 210 S.C. 56, 41 S.E.2d 599 (1947) ; cf. In re Public Industrials Corp., 19 Del. Ch. 398, sub nom. In re Chilson, 168 At1. 82 (Ch. 1933) (voting contract).

47. E.g., Roberts v. Whitson, 188 S.W.2d 875, 878 (Tex. Civ. App. 1945) (agreement to vote collectively for ten years, providing for arbitration, held revocable because not coupled with an interest nor "based upon consideration deemed valuable in law").

48. Cases are cited in 5 Fletcher, Cyclopedia of Corporattons $\$ 2064$ n. 39-40 (perm. ed. 1933); Note, 71 A.L.R. 1289, 1291 (1931); Comment, 46 MICH. L. Rev. 70 n. 1 (1947).

49. Laughlin v. Johnson, 230 I11. App. 25 (1923); 3 Cook, Corporatrons §622a (1923) ; 15 U. OF CHI. L. Rev. 738 (1948).

50. See note 58 infra and text.

51. Williams v. Frederick, 187 La. 987, 175 So. 642 (1937) ; McQuade v. Stoneham, 263 N.Y. 323, 189 N.E. 234 (1934). The contracts would have made directors mere "dummies." Ford v. Magee, 160 F.2d 457 (2d Cir. 1947) ; Manson v. Curtis, 223 N.Y. 313, 119 N.E. 559 (1918). Other cases were disposed of on the principle that a shareholder may not sell his vote for a private consideration. Stott v. Stott, 258 Mich. 547, 242 N.W. 747 (1932) ; Cone's Ex'rs v. Russell, 48 N.J. Eq. 208, 21 At1. 847 (Ch. 1891) ; Luedke v. Oleen, 72 N.D. 1. 4 N.W.2d 201 (1942).

52. Faulds v. Yates, 57 I11. 416 (1870); Brightman v. Bates, 175 Mass. 105, 55 N.E. 809 (1900). 
these dicta render uncertain the enforceability of such contracts in many jurisdictions, other courts have expressly refused enforcement on grounds of public policy. ${ }^{53}$ In the residuum of cases, where courts have accorded the parties the full equivalent of specific performance, the separation of voting power from ownership was warranted by a financial commitment in the welfare of the corporation similar to that deemed necessary by most courts for the validation of an irrevocable proxy.54 In Smith v. San Francisco $R y .{ }^{55}$ for example, the parties were induced to contribute funds sufficient to purchase majority ownership by an agreement among themselves that the shares would be voted for five years as the majority should direct. When a bolting party attempted to cast his own vote in opposition to that cast by the majority, the court granted specific performance of the agreement, ${ }^{56}$ recognizing the security need of those who had contributed substantially to the corporate assets. .5

Where the parties own all the stock, voting contracts are fully enforced. Restriction upon freedom of contract is imposed only when there is a nonconsenting minority of owners. This constitutes judicial recognition of the minority's right to have all owners of voting stock free to express their self-interest.58 That there is no legal objection to purchasing control by buying a majority of voting shares buttresses this conclusion..$^{99}$ A similar policy prohibits the sale of votes for a private consideration. ${ }^{60}$

53. Morel v. Hodge, 130 Ga. 625; 61 S.E. 487 (1908) ; Haldeman v. Haldeman, $176 \mathrm{Ky} .635,197$ S.W. 376 (1917) ; Odman v. Oleson, 319 Mass. 24, 64 N.E.2d 439 (1946); Gage v. Fisher, 5 N.D. 297, 65 N.W. 809 (1895); Roberts v. Whitson, 188 S.W.2d 875 (Tex. Civ. App. 1945).

54. Venner v. Chicago City Ry., 258 IIl. 523, 101 N.E. 949 (1913) ; Hart v. Bell, 222 Minn. 69, 23 N.W.2d 375 (1946) ; Trefethen v. Amazeen, 93 N.H. 110, 36 A.2d 266 (1944); Miller v. Vanderlip, 285 N.Y. 116, 33 N.E.2d 51 (1941) semble; White v. Snell, 35 Utah 434, 100 Pac. 927 (1909); Winsor v. Commonwealth Coal Co., 63 Wash. 62, 114 Pac. 908 (1911). In one of the cases sometimes cited to uphold contracts, the owner merely perpetuated his control after death by directing trustees in whose names the shares were bequeathed to vote for themselves as directors. In re Pittock's Will, 102 Ore. 159, 199 Pac. 633 (1921). Weber v. Della Mountain Mineral Co., 14 Idaho 404, 94 Pac. 441 (1908) involved only a combination of stockholders not bound by contract. In Thompson v. Thompson, 279 Ill. 54, 116 N.E. 648 (1917), conflicting property interests in the shares were resolved, and the court gave the voting rights to the party adjudged sole owner of the shares.

55. 115 Cal. 584, 47 Pac. 582 (1897).

56. The court, having implied a proxy as necessary to carry out the agreement, held it irrevocable, being "in the nature of a power coupled with an interest." Two of the three shareholders agreed to vote their shares jointly for ten years, the decision of an arbitrator to be binding if they could not agree. $D$ voted contrary to the arbitrator's award. The court held that his votes should not be cointed, but that no proxy could be implied. Ringling Bros.-Barnum \& Bailey Combined Shows v. Ringling, 53 A.2d 441 (Del. Sup. Ct. 1947), 96 U. of PA. L. REv. 121 (1947), 60 Harv. L. Rev. 651 (1947), 46 MICH. L. Rev. 70 (1947), 15 U. of CHI. L. REv. 738 (1948).

57. After this decision it was provided that every proxy should be revocable. CAL Civil Code \$321(b) (Deering, 1923). In Simpson v. Nelson, 77 Cal. App. 297, 246 Pac. 342 (1st Dist. 1926), this section was held to invalidate an agreement similai to that of the principal case after revocation. Later statutory provisions recognize a proxy coupled with an interest. CAL. CORP. CODE $\$ 2228$ (Deering, 1948).

58. Kantzler v. Benzinger, 214 Ill. 589, 73 N.E. 874 (1905); Hayden v. Beane, 293 Mass. 347, 199 N.E. 755 (1936); Clark v. Dodge, 269 N.Y. 410, 199 N.E. 641 (1936); Application of Kirshner, 81 N.Y.S.2d 435 (Sup. Ct. 1948), 47 MrcH. L. REv. 580 (1949); In re Block's Will, 186 Misc. 945, 60 N.Y.S.2d 639 (Surr. Ct. 1946) ; Davis v. Argus Gas \& Oil Co., 167 Misc. 377, 3 N.Y.S.2d 241 (Sup. Ct. 1938) ; Baran v. Baran, 59 Pa. D. \& C. 556 (C.P. Luz. Co. 1947).

59. In Foll's Appeal, $91 \mathrm{~Pa}$. 434 (1879), the court refused specific performance of a contract to sell shares, whose avowed purpose was to give control to one who had purchased his holdings with borrowed money. "The temptation to use it for personal ends, in such case, is very strong." Id. at 438.

60. See text at note 6 supra. 
Since mutual promises are not sufficient consideration, and votes may not be purchased, effective divorce of the vote from stock ownership by contract is difficult. ${ }^{61}$

\section{Control of Business Corporations}

Those who would abandon the policy against separating voting power irrevocably from ownership of the shares urge that the power to vote should be treated as a transferable property interest, rather than a right personal to the owner for the protection of all shareholders. ${ }^{62}$ They argue that the basis of the old policy is the obviously untenable theory of the contract between members for each other's individual judgment, that the disinterest of the average investor in voting furnishes reason for permitting him to sell his vote for profit, ${ }^{63}$ that the voting trust and the scattered ownership of large corporations illustrate that separation has already been achieved, and that a policy against achieving it by contract or proxy is unrealistic. Further, it is said, the burden of regulating voting agreements should be left to legislatures, and courts should restrict their activity to invalidating voting agreements for proven fraud. ${ }^{64}$ Finally, it is contended that enforcement of contracts between shareholders for stabilized control to carry out long range policies is beneficial to all owners. ${ }^{65}$

The current worth of the old policy can be evaluated only after examining the interests of control separated from ownership. ${ }^{66}$ It is worth repeating that the power to elect directors contains the ability to apportion earnings among the interested groups--owners, employees, consumers, or the control group itself - and that corporate contracts and salaried positions are patronage. ${ }^{67}$ Where a majority in ownership retains the power to control, the self-interest of the profit group is always free to assert itself. ${ }^{67 a}$ As the ownership of the control group decreases, however, it is increasingly possible that groups other than those of ownership will receive the bulk of earnings, and the temptation to overlook the interest in distributed profits increases. ${ }^{68}$

Assuming that self-interest will guide the policies of the control group, free negotiability of voting rights defeats the traditional concept that management must always be legally subject to removal periodically

61. See Comment, 46 MICH. L. Rev. 70 (1947) passin (analysis of precautions to be taken in drafting voting agreements).

62. Rohrlich, Corporate Voting: Majority Control, 7 Sr. JoH N's L. Rev. 218, 225 (1933); Comment, 47 MICH. L. Rev. 547, 553 (1949). Macht v. Merchants' Mortgage Co., 22 Del. Ch. 74, 194 Atl. 19 (Ch. 1937) presents an opposing view.

63. Rohrlich, supra note 62 , at 225 .

64. Comment, 47 MICH, L. REv. 547, 555 (1949).

65. It may be argued that the sacrifice of democratic control by shareholders has brought more social profit than loss. TIPPETS AND LIVERMORE, Business ORganizaTION AND CONTROL 111 (1941).

66. Berde and Means, The Modern Corporation and Prdvate Property (1933) is instructive, especially ch. V and VI, pp. 69 and 119. Compare RoHrLICH, LAw aNd Practise in CoRporate Control (1933).

67. Hornstein, Corporate Control and Private Property Rules, 92 U. of PA. L. Rev. 1, 3 (1943).

67a. This statement is not strictly true of those corporations whose commanding position in the economy subjects them to a great pressure of public opinion which constitutes an important limitation upon the freedom of action of the owners and managers. This discussion, however, confines itself to small corporations which do not fall into this category.

68. Overfield v. Pennroad Corp., 42 F. Supp. 586 (E.D. Pa. 1941) (power and funds of the corporation used primarily to benefit another corporation rather than investors). For examples of indirect ways of diverting a part of earnings for the benefit of those in control, see BERLE AND MEANS, op. cit supra note 66, at 123 . 
by the assertion of the self-interest of a majority of owners. When the court permits a shareholder to vote as he pleases despite his contract, it is protecting other nonconsenting owners primarily, not the shareholder who has sold his vote. The effectiveness of the safeguard depends largely, of course, upon the shareholders' knowledge of the corporate affairs, so that the vote may be cast intelligently.

In very large corporations, control is often separated from ownership without the use of a legal device, simply because of widely scattered ownership. Management with little or no ownership becomes entrenched through availability of (the proxy machinery, use of corporate funds, and the prestige of incumbency. Owners are factually disenfranchised. ${ }^{69}$ But since 1934, the Federal Security Acts have provided that solicitation of proxies for certain stocks shall be subject to agency regulation. ${ }^{70}$ Following the legislative policy that ownership should have a legal right to exercise its potential power of control, ${ }^{71}$ the Securities and Exchange Commission has required solicitors of proxies to make fuller disclosure and to provide opportunity to register dissent from, as well as approval of, management schemes. ${ }^{72}$ Effective separation by use of the voting trust, likewise, is largely a legislative creature, and therefore subject to strict regulation. Usually the statute requires that the control group make itself known, ${ }^{73}$ and subjects it to fiduciary obligations in managing the corporation. ${ }^{74}$ It is apparent, therefore, that the policy against separating control from ownership is still asserting itself.

69. Berle ANd MEANS, op. cit. supra note 66, at 88-9. See excerpts from the legislative history of the Federal Security Acts, note 71 infra.

70. Section 14 of the Securities and Exchange Act, 48 STAr. 895 (1934), 15 U.S.C. $\$ 78 \mathrm{n}$ (1946) (principal limitation the requirement of listing on a national exchange). The SEC also supervises the proxy regulations of $\$ 12(\mathrm{e})$ of the Public Utility Holding Company Act, 49 STAT. 824 (1935), 15 U.S.C. $\$ 791(\mathrm{e})(1946)$, and $\$ 20$ of the Investment Company Act, 54 STAT. 822 (1940), 15 U.S.C. $\$ 80(a-20)$ (1946) (proxies for securities of registered holding companies or their subsidiaries, and for securities of registered investment companies).

71. "Insiders have at times solicited proxies without fairly informing the stockholders of the purpose for which the proxies are to be used and have used such proxies to take from the stockholders for their own selfish advantage valuable property rights. . For this reason the proposed bill gives the ${ }^{-}$. Commission power to control the conditions under which proxies may be solicited with a view to preventing the recurrence of abuses which have frustrated the free exercise of the voting rights of stockholders." H.R. REP. No. 1383, 73d Cong., 2d Sess. 13, 14 (1934).

"Subsection (e) of Public Utility Holding Co. Act of 1935, § 12 covers the solicitation of proxies . . . so that such solicitation will not afford the basis for subtle control adverse to the interests of investors who have a right to be kept fairly and properly informed by representatives of their own choosing as against selfish, selfconstituted, self-perpetuating cliques." SEN. REP. No. 621, 74th Cong., 1st Sess. 35 (1935).

72. S.E.C. Reg. X-14, 2 CCH Fed. Securities Law Serv. (2d ed.) II 25,60125,611 (1947); S.E.C. Rules U-60 to U-65, 3 CCF Fed. SECURITIES LAW SERV. (2d ed.) IIT 38,701-38,751 (1941) ; S.E.C. Rule N-20A 1, 3 CCH FED. SECURITIES LAW SERv. (2d ed.) I 49,701 (1944) ; Bernstein and Fischer, The Regulation of the Solicitation of Proxies: Some Reflections on Corporate Denocracy, 7 U. OF CHI. L. REv. 226 (1940); Note, 21 TEMrP. L.Q. 406 (1948).

73. See 5 Fletcher, Cyclopedia of Corporations, $\$ 2080$ n. 4 (perm. ed. 1933) for a compilation of state statutes authorizing voting trusts. The need for regulation of such devices has been recognized. Ballantine, Voting Trusts, Their Abuses and Regulation, 21 TEX. L. REv. 139 (1942).

74. Overfield v. Pennroad Corp., 42 F. Supp. 586 (E.D. Pa. 1941). 


\section{CoNCLUSION}

Although some courts have quietly abandoned them, judicial restrictions on the transferability of voting rights independently of ownership are still needed. Legislative acquiescence in such devices as nonvoting stock and voting trusts is not a sufficient reason for the courts to let the bars down further. Instead of representing merely archaic restraints upon shareholders' freedom of contract, these restrictions furnish a modern standard for the judicial enforcement of a paramount scheme of corporate "dollar democracy." No control group is entitled to deprive the majority of owners from securing a change in management at election time, except in the unusual circumstances where it has made a substantial financial commitment to the welfare of the corporation so as to merit a security need of control. Otherwise the control group is entitled to no greater security than the prestige of an efficient, competitive, and successful period of management, plus the support of its own ownership votes. The inauguration of a policy of free transferability of voting rights is contrary to the interests of all minority shareholders.

T. T.

\section{The Appearance of Legislators as Private Counsel in State Administrative Adjudications}

In the continuing quest for improvement of administrative adjudication, it has been suggested that the appearance of state legislators as counsel for private ${ }^{1}$ parties creates an atmosphere likely to produce determinations tainted by improper considerations. ${ }^{2}$ There are strong indications that this charge is true and that numerous instances of undesirable results have occurred. ${ }^{3}$ This Note will explore the relationship which legislators

1. Legislators sometimes appear as counsel for the state in adjudicatory proceedings; but the danger of improper influence there does not seem to be serious or widespread, especially in view of the usual laws prohibiting any one person from holding more than one office at the same time. E.g., MoNr. Const. Art. V, \$ 7; PA. STAT. ANN., tit. 65, \$ 16 (Purdon, 1941) ; Saint v. Allen, 169 La. 1046, 126 So. 548 (1930) (violation of Louisiana state constitution for legislator to act as counsel for branch of executive department).

2. Benjamin, Administrative Adjudication in the State of New York 123 (1942). In 1942 Senate Bill No. 96 was introduced in the Senate of New Jersey "to prevent members of the Legislature from appearing before any commission, department, body or agency of the State of New Jersey on behalf of any person or corporation inasmuch as such appearance or representation would be inconsistent with the duty of a legislator." In 1947 House Bill No. 485 was introduced into the Michigan Legislature for the same purpose. Neither bill was enacted.

3. "There has developed in this, and a few other states the practice of legislators appearing as counsel for interested parties before certain boards and commissions. This is a deplorable condition. I have in mind a former senator who appeared in numerous cases representing certain clients, before the Public Service Commission. I also have in mind certain members who in the past, have appeared in behalf of clients before the Liquor Control Commission. Others have appeared many times before the Department of Labor and Industry." Inaugural Message of Governor IKim Sigler of Michigan, January, 1947. 1 Michigan House Journal 54 (1947).

"The writer knows of certain instances where the attorney for the person appearing before the agency was a member of the legislature. This had a material effect upon the administrative agency by reason of the fact that the attorney was a member of the legislature and at some future time might make things embarrassing for the agency, if it should incur his displeasure by adverse rúlings." Letter to the REview, from the Office of Attorney General of North Dakota, dated Feb. 12, 1949.

Similar views have been expressed in personal interviews and letters from practitioners, government officials, and experts on political science. 
bear to administrative agencies and, in that light, will discuss the desirability of permitting the practice to continue.

Representation in administrative proceedings is carried on by members of the legislature certainly in most states and probably in all. ${ }^{4}$ No state statute has been discovered which tends to prohibit or discourage such practice; and although many agencies have some freedom to promulgate regulations limiting practice before them to certain qualified persons, ${ }^{5}$ it is unlikely that such power includes the power to exclude legislators per se. ${ }^{6}$ Lawyers comprise a substantial segment of state legislatures, ${ }^{7}$ and the legislator who represents private parties in agency proceedings is usually a lawyer. Although exact figures are not available, it is believed that the number of members of a given legislature who engage in administrative practice is relatively small. ${ }^{8}$ Instances of abuse, however, are numerous.

It is regretted that out of respect for obliging sources, details of known instances of abuse cannot be recounted, but perhaps hypothetical cases will point up the dangers, prompting both memory and imagination.

1. During a spring flood, Cherry Bridge was damaged and, in the interest of public safety, the Public Utility Commission lowered the maximum load limit for vehicles using the span, thereby reducing the toll revenue. Bridge Company was unable to get the limit raised again, but Senator $\mathrm{X}$ took the case on contingent fee, and on rehearing the Commission was persuaded, without new evidence, that the original limit should be reinstated.

2. Milk distributor was operating with facilities which Milk Control Board, in a formal hearing, determined to be unsanitary. A new

4. "Members of the Arkansas General Assembly practice extensively before the Workmen's Compensation Commission, the Public Service Commission, and the Board of Fiscal Control, sitting as the State Claims Commission. They also have a considerable practice before the Commissioner of Revenues, who is authorized by law to conduct hearings in connection with certain tax matters and the control of alcoholic beverages." Letter to the REviEw from the Office of Attorney General of Arkansas, dated Feb. 26, 1949.

"Members of the Legislature very often appear before the various administrative bodies in this state. . " Letter to the Review from the Department of Justice of Mississippi, dated Feb. 14, 1949.

"There is no law prohibiting any member of the legislature from appearing on behalf of his clients before these agencies and members of the legislature frequently do appear." Letter to the REvIEW from the Office of Attorney General of North Dakota, dated Feb. 12, 1949.

"There are, in fact, a number of such members [of the General Assembly of Pennsylvania] rather prominent in practice before such agencies." Letter to the REvIEw from Legislative Reference Bureau of Pennsylvania, dated Feb. 16, 1949.

5. For a comparative analysis of federal agency regulations, see Cragun, Admission to Practice: Present Regulations by Federal Agencies, 34 A.B.A.J. 111 (1948).

6. Opinions expressed informally in letters to the REvIEw from the offices of attorneys general of Indiana, Louisiana, Maine, Mississippi, New Hampshire, and South Dakota. The statutes, of course, in particular cases are controlling.

7. The following is a tabulation of the percentage of lawyers in the two houses of the Pennsylvania General Assembly:

$\begin{array}{llllll} & 1921 & 1935 & 1939 & 1943 & 1947 \\ \text { House: } & 20 \% & 17 \% & 20 \% & 18 \% & 15 \% \\ \text { Senate: } & 36 \% & 34 \% & 44 \% & 42 \% & 42 \%\end{array}$

The national average of lawyers in state legislatures (both houses) from 1931 to 1937 was $24.2 \%$. WALKer, The Legislatrve Process 148 (1948).

8. Based on interviews with persons familiar with the practice, and on results of questionnaires directed to attorneys general of the various states. There is a general lack of published reports of proceedings before most state agencies and the reports available do not include all proceedings at all stages. 
installation being costly, Milk Dealer got Senator $A$ to obtain a rehearing at which the Board concluded that the milk was not being contaminated after all.

\section{The Solution of the Federal Government}

Since $1864 \mathrm{a}$ federal statute has provided that members of Congress and other officers of the federal government may not receive compensation for services rendered as counsel in relation to any matter in which the United States is interested. ${ }^{9}$ Although the statute fails to prohibit the practice altogether, the effect is substantially the same since remuneration is denied. Its broad coverage was interpreted to include practice by Congressmen before administrative agencies in 1906, when a Senator was sentenced to fine and imprisonment for taking compensation as counsel in a mail fraud order proceeding before the Postmaster General. ${ }^{10}$ In upholding the constitutionality of the statute, the court said:

"The proper discharge of those [Senatorial] duties does not require a Senator to appear before an executive department in order to enforce his particular views, or the views of others, in respect to matters committed to that department for determination. He may often do so without impropriety, and, so far as existing law is concerned, may do so whenever he chooses, provided he neither agrees to receive nor received compensation for such service. Congress, when passing the statute, knew, as, indeed, everybody may know, that executive officers are apt, and not unnaturally, to attach great, sometimes, perhaps, undue, weight to the wishes of Senators and Representatives. Evidently, the statute has for its main object to secure the integrity of executive action against undue influence upon the members of that branch of the government, whose favor may have much to do with the appointment to, or retention in, public position of those whose official action it is sought to control or direct. The evils attending such a situation are apparent and are increased when those seeking to influence executive officers are spurred to action by hopes of a pecuniary reward." 11

The federal statute's comprehensive coverage tends to prevent Congressmen and members of the executive branch from espousing particular interests before adjudicatory bodies, but influencing which goes on behind the scenes is an unremedied facet of the problem which may stem from the legislature's dominance over agency personnel. ${ }^{12}$

\section{The Federal Solution for the State Problem}

No state has taken statutory steps to reduce the practice of legislators before administrative bodies over which they hold a position of dominance; and although many agencies have a degree of freedom to determine who may appear as counsel, none has attempted to restrict practice by legislators

9. 18 U.S.C. $\$ 203$ (1948).

10. Burton v. United States, 202 U.S. 344 (1906).

11. Id. at 348 .

12. "However, we do not recall any instance in this State that resulted in an abuse of the functions of a commission resulting solely from the relationship mentioned [appearance by legislators in administrative proceeedings]." Letter from State of Wyoming to $\mathrm{E}$. W. Capen, see note 13 infra. 
otherwise qualified. ${ }^{13}$ It has been suggested that these evils might be overcome by legislation patterned on the federal statute. ${ }^{14}$ So drastic a remedy ought to be accepted only if critical analysis fails to disclose a more desirable one. Such a proposal also fails to recognize the fundamental differences between federal and state circumstances.

Members of state legislatures are not expected to devote their full time to legislative duties during their tenure of office. Legislatures are out of session most of the time, ${ }^{15}$ and salaries and allowances in most states are scaled accordingly. ${ }^{16}$ Highly competent persons cannot be expected to forego the fruits of their professions for the modest salary of a state legislator. Lawyers, accountants, engineers, and other highly trained specialists are necessary to compose a legislative body fit to handle the problems facing state governments, but such men command greater remuneration for their services from private sources than they can expect to get from governmental positions. Under existing conditions, these men must be allowed to keep their private practices or the legislatures will convene without them. Even if legislators' salaries could be greatly increased, the uncertainty of reelection would deter many persons from giving up lucrative private activities. ${ }^{17}$

It may be argued that one need not give up all his practice, but merely that which requires him to appear before agencies of his own state. In the case of many professional men such an argument is unrealistic. Governmental activity is too broad for the average lawyer to avoid contact with state agencies in the course of representing his clients. Workmen's compensation claims, rate regulations by public utility commissions, many types of licensing requirements, and revenue collections represent some of the usual forms of state administrative activity which give rise to much legal work. It is a harsh requirement which would have a lawyer tell his clients that he can handle some of their problems but not those involving state administration. A client wants counsel who can represent him in all matters. He is not satisfied with an accountant who can prepare his tax return, but will be unable to appear before a revenue board should it be contested. He wants a lawyer who can not only carry through a land transaction, but can also appear before a board of revision to seek a reduction in assessed value.

The member of Congress, on the other hand, receives a considerably higher salary ${ }^{18}$ and an immeasurably greater degree of eminence. Ai-

13. See a survey by E. W. Capen showing "state attitudes towards permitting the practice of members of their respective legislatures before boards and commissions whose personnel is appointed by them or confirmed by them after nomination by the governor." South Carolina Industries, Inc., Political Integrity Series Report, September 1948.

In Maine, a member of the Legislature is not allowed to appear as attorney or agent before legislative committees. Ietter to the REVIEw, from Department of the Attorney General, dated Feb. 23, 1949.

14. See note 1 supra. Compare, however, the common statutes which prohibit judges from practicing law, e.g., PA. STAт. ANN., tit. 17, \$1607 (Purdon, 1930). sions.

15. The term is generally 60 days each biennium with possibility of special ses-

16. Salaries range from $\$ 5,000$ per year in New York to $\$ 5$ per day of session in Rhode Island. For a complete tabulation, see Salaries and Compensation of State Legislators, 22 STATE GOVERNMENT 50 (1949).

17. For a tabulation of the average number of terms spent in state legislatures by individual legislators, see Walker, op. cit. supra note 7 , at 148 ; Graves, AMERICAN State Government 238 (3d ed. 1946).

18. Congressmen receive, in addition to an annual salary of $\$ 12,000$, a tax exempt sum of $\$ 2,500$ for expenses and $20 \phi$ per mile for travel to and from regular sessions. 
though he too is subject to the changing tide of political fortunes, the prominence attached to Congressional service is an asset that continues after his term is over and is of substantial value in re-establishing private practice.

One suggested alternative is to increase the emoluments of state legislative service to the point where competent men might be induced to give up private practice. Aside from the fact that it is unreasonable to raise all legislative pay to the point needed to attract men of the highest income capacity, the resulting increase in expense is not an efficient investment unless we are prepared to insist that membership in a state legislature be a full time job. ${ }^{19}$ Furthermore, even where the practice exists, unwholesome results are not inevitable. Not all legislators and agency members are susceptible to unethical pressure, and it is neither desirable nor necessary to penalize those legislators who maintain proper relationships with administrative bodies.

\section{Possible Solutions}

Administrative agencies perform functions of legislature, executive, and judiciary in particular fields. Whether constituted within the executive department, or as independent commissions, they must be subject to control in varying degrees by the three branches of the government. As arms of the legislature engaged in the filling in of details under general statutes, as well as in the making of ad hoc rulings consistent with the pattern of formulated policy, agencies must be responsive to the legislature. To the extent that the rights of individuals are affected in the application of policy, the courts have jurisdiction to review procedural and constitutional questions. ${ }^{20}$ The executive branch, too, has a great interest in the operation of the agencies because, in the broader aspect, the administration of policy is its function.

The problem at hand arises out of those elements of control retained by the legislature. Appropriations must come from it with or without the approval of the executive ${ }^{21}$ internal organization and procedure is established and regulated to a considerable extent by it; the appointment of key members of the agency is subject to its approval. ${ }^{22}$ In addition, the legislature has the powers of impeachment ${ }^{23}$ and investigation. ${ }^{24}$ Many states at 170 .

19. For well considered opinion to this effect, see WALKER, op. cit. sipra note 7,

20. Even where statutes have not provided for judicial review of agency determinations, courts have assumed that function. See Brown, The Use of Extraordinary Legal and Equitable Remedies to Review Executive and Administrative Action in Massachusetts, 21 B.U.L. REv. 632 (1941), 22 id. 55 (1942). But such review is limited by the requirement that administrative remedies be exhausted. See Notes, 14 Geo. Wash. L. Rev. 377 (1945) and 44 Mich. L. Rev. 1035 (1946).

21. E.g." "No money shall be paid out of the treasury except upon appropriation made by law. . . " PA. CoNST. ART. III, \$16. "The Governor shall have power to disapprove any item or items of any bill, making appropriations of money, . . . and the part or parts of the bill approved shall be the law, and the item or items of appropriation disapproved shall be void, unless repassed. . " PA. CoNst. ART. IV, § 16.

22. E.g., "The Governor shall nominate and, by and with the advice and consent of two-thirds of all the members of the Senate, appoint: . . (b) Except as in this act otherwise provided, the members of all departmental administrative bodies, boards and commissions. . ." PA. STAT. ANN., tit. 71, \$ 67 (Purdon, 1942).

23. E.g.," "The Governor and all other civil officers shall be liable to impeachment.

24. See Legislative Investigations, 9 INT'L Jurm. Ass'N BurL. 73 (1941). Colorado has a legislative committee empowered to investigate "any department or agency of the state government or any state institution, and.+ any of the officers and employees thereof." CoLo. STAT. ANN., c. 74, $\$ 30-36$ (Supp. 1947). 
also have legislative councils which maintain liaison between administrative agencies and the legislature with respect to matters of budget, personnel, operation, and organization..$^{25}$

Improper influence on administrative decisions is likely to be effective when the sympathy of a particular legislator or group of legislators comprising a controlling committee is necessary to secure enactments of agencydesired legislation or to kill proposals adverse to the interests of the agency. The power of investigation is particularly susceptible of abuse. Short of an actual investigation, its mere recommendation not only brings an agency into public distrust, but paralyzes activity in anticipation. So long as appointments are primarily political and require the consent of any part of the legislature, an additional pressure-point exists where the agency member's term is for years and he is eligible to succeed himself, as is generally the case. Nor is it advisable to make administrators ineligible for reappointment: there is need to retain experienced men in office, since expertness is the very reason for having specialized agencies to administer detailed programs. Because appointments normally need ratification only by them, and because of their greater individual importance, members of the upper house or Senate have more power to exert influence.

A certain degree of legislative control over agencies is necessary, but reduction of undesirable practices can be achieved in two ways: (1) by decreasing the nature and degree of control to the minimum required for legitimate purposes, and (2) by reducing the opportunities for individual abuse of whatever controls need be retained. Improvement in the organizational relationships between governmental departments would reduce opportunity for abuse. Opportunity to exert undue influence, however, does not exist in all agencies, and because of peculiar characteristics, individual agencies which do require remedies should be treated individually. ${ }^{26}$ The ultimate solution, to have legislators and agency members of high moral integrity, is a problem for the electorate. For these reasons, no proposal of broad solutions will be made. To aid in focusing upon the problems of particular situations, however, it is useful to consider those factors which are pertinent to agency proceedings in general.

There seems to be no great danger in appearances in quasi-legislative hearings, ${ }^{27}$ where the agency operates as an arm of the legislature, and, ordinarily, varied representation and publicity exist. For example, proceedings before a public utility commission on a rate increase or decrease get wide publicity and many groups have the right to be heard. Judicial review, also, gives the courts opportunity to correct flagrant abuses arising in formal proceedings: administrative findings must be supported by evidence; ${ }^{28}$ hearing officers must be free from bias and prejudice; ${ }^{29}$ there

25. Such councils are sometimes staffed by legislators whose practice before administrative agencies would seem to be particularly undesirable. Thirteen states have legislative councils. See Perkins, State Legislative Reorganization, 40 Axr. PoL. Scr. REV. 510 (1946).

26. Agency organization is as varied as the needs giving rise to the agencies, and for this same reason uniformity of agency procedure and organization is not feasible. See BENJAMIN, op. cit. supra note 2, at 24 et seq.

27. The dichotomy between "quasi-legislative" or "rule-making" and "adjudicatory" or "quasi-judicial" is observed in the Federal Administrative Procedure Act. 60 StAT. 237 (1946), 5 U.S.C. $\$ 1001$ (1946), as amended, 61 STAT. 37 (1947), 61 STAT. 201 (1947), 5 U.S.C. \$ 1001 (Supp. 1948).

28. E.g., Northern Pacific Ry. v. Department of Public Works, 268 U.S. 39 (1925) (even without statutory requirement).

29. E.g., Clark v. Alcoholic Beverage Comm'n, 54 R.I. 126, 170 Atl. 79 (1934) (hearing officer disqualified because of personal interest). But cf. Georgia Continental Telephone Co. v. Georgia Public Serv. Comm'n, 8 F. Supp. 434 (N.D. Ga. 1934) 
must be an opportunity to be heard, ${ }^{30}$ and to cross-examine witnesses. ${ }^{31}$ In those cases, however, which never get to the courts, opportunity for abuse is greater. As an example, ex parte proceedings before a tax board will not get to the appeal stage in the event of connivance between the taxpayer's attorney and the board. On the other hand, in a hotly contested case before a workmen's compensation commission where both employer and employee are represented in a formal hearing, the prospect of judicial review and publicity will hamper the effectiveness of improper influence.

Absent publicity, adverse parties, and the possibility of review, high standards of ethics should be fortified by reducing opportunities for abuse. Legislators who are members of legislative committees having to do with particular agencies should be precluded from practice before those agencies, and participation by adverse parties in ex parte proceedings should be encouraged. In licensing proceedings, for example, notice and opportunity to participate should be given to civic groups and competitors. In determining who is an "interested" party, the courts should recognize that such representation reduces opportunity for abuse.

Some means must be maintained to prevent legislative policy from being frustrated by unsympathetic independent administrative bodies. Fortunately, the degree of control which the legislature needs over adjudicatory functions is less than that required over quasi-legislative proceedings where opportunities for abuse are inherently fewer. ${ }^{32}$ Agencies which are expected to reflect the dominant political philosophy require a more immediate responsibility to the legislature; those agencies which make few or no policy decisions can be isolated more safely. The chief reasons for giving adjudicative powers to an agency rather than to the courts do not suggest a need for close legislative control. ${ }^{33}$ Determinations of fact should be free from policy considerations, although policy may be regarded as a basis for indulging in presumptions and allocating the burden of proof. Of course, when the facts have been ascertained, policy is a proper influence in applying rules. A separation of functions, therefore, within certain agencies, would be profitable in order to relieve adjudicatory officers from unnecessary subordination to the legislature. Other reasons, too, dictate the desirability of separating quasi-judicial from quasi-legislative functions. ${ }^{34}$ To grant hearing officers the status of judges with respect to security and political independence, in addition, is not inconsistent with effective administration and would tend to reduce further the opportunity for abuse in ex parte proceedings. Any reorganization, however, must contend with such considerations as cost and size of agency.

(allegation of duress not sufficient to disqualify commissioner and render ruling invalid, where such duress was threat of governor to remove commissioners if they did not reduce telephone rates).

30. E.g., Randall v. Patch, 118 Me. 303, 108 Atl. 97 (1919) (required by due process).

31. This is required generally only in an adjudicatory hearing. Sabre v. Rutland R.R., 86 Vt. 347, 85 Atl. 693 (1913) ; see Colteryahn Sanitary Dairy v. Milk Control Commission. 332 Pa. 15, 21, 1 A.2d 775, 779 (1938).

32. See note 27 supra and text following.

33. The requirements of dispatch, expertness, and uniformity of application could not be as well met by the numerous courts, which have crowded calendars and lack familiarity with the ramifications of technical administrative problems.

34. Benjamin, op. cit. supra note 2 at 44-71. The Federal Administrative Procedure Act, 60 STAT. 239, 5 U.S.C. $\$ 1004$ (c) (1946), provides for the separation of functions to guard against bias and intra-agency influence. Protection of hearing officers from legislative influence could be achieved without disturbing the relations between the legislature and the policy formulators within the agency. See Davis, Separation of Functions in Administrative Agencies, 61 HARv. L. Rev. 389 (1948). 
In certain agencies, legislative control might be reduced safely by establishing fiscal independence through the assessment of costs against parties appearing before the agency, ${ }^{35}$ and in such noncontroversial administrative activities as ordinary licensing, revenue collection, and health and sanitary inspections, agency personnel could be isolated from legislative control by a strong civil service program. ${ }^{36}$ Finally, the bar associations have a continuing obligation to scrutinize administrative practice for violations of legal ethics.

An approach along the lines suggested has the additional advantage of reducing the opportunity for improper legislative influence through indirect channels, whereas banning the practice of legislators before administrative agencies merely forces the use of less apparent means. These opportunities for abuse furnish an important reason for every state to review critically its agency organization.

$$
\text { J. G. McC. III. }
$$

\section{Toward the Standardization of Pennsylvania Motor Vehicle Liens}

The principal property of a large segment of the American population is the family car, ${ }^{1}$ and in 1948, two-fifths of such automobiles were purchased under installment sale contracts, ${ }^{2}$ partly because of the current popularity of the "installment plan," but probably even more because of the relatively large investment required. Furthermore, the large size of the investment and the ease of resale make automobiles readily acceptable as collateral security for a loan. These two widespread practices, purchase of automobiles under installment sale contracts, and their use as collateral security, explain why the volume of security transactions involving motor vehicles is enormous. ${ }^{3}$ Clear and adequate law should govern these transactions and, in recent years, Pennsylvania has made notable progress towards developing such laws, although it has not yet completed the job. Pertinent provisions of the Vehicle Code ${ }^{1}$ and the recently enacted Motor Vehicle Sales Finance Act ${ }^{5}$ greatly facilitate and protect commercial activity in this field. However, a variety of security devices still exists, making the legal consequences of a transaction partly dependent upon the device employed. This Note will review the evolution of Pennsylvania motor vehicle lien law, point out difficulties which result from the non-standardization of these security devices and suggest statutory amendments as possible remedies.

35. This is done to a certain extent in some agencies. E.g., PA. STAr. ANn., tit. 66, \$1461 (Purdon, Supp. 1948) (Public Utility Commission).

36. "There has been very little abuse in Wisconsin on this score, and I think the reason chiefly is that all of the personnel and many of the department heads of administrative agencies are under civil service so that they are less likely to be sensitive to legislative pressure than would be the case if our state government were operated under the spoils system." Letter from Office of Attorney General of Wisconsin, dated March 2, 1949.

1. Half the nation's families own at least one car. 35 Fed. Reserve Buld. 335 (1949).

2. The purchase of automobiles is the most important source of demand for consumer installment credit. Ibid.

3. The amount of this credit currently outstanding is approximately $\$ 2,700,000,000$. About $\$ 2$ billion of this amount originated with dealers. Ibid.

4. PA. Stat. AnN., tit. 75, \$\$ 31-43 (Purdon, Supp. 1948).

5. Pa. Stat. AnN., tit. 69, $\$ \$ 601-637$ (Purdon, Supp. 1948). 


\section{Liens Arising from Purchase}

The need for a method which enabled sellers safely to defer payment for goods currently delivered existed long before the creation of statutory security devices. ${ }^{\bullet}$ Until a relatively short time ago, however, the law of Pennsylvania held transfer of title and of possession necessarily contemporaneous incidents of a valid sale, ${ }^{7}$ and retention of a security title was void as against the rights of subsequent parties acquiring an interest in the property for value in good faith. ${ }^{8}$ To save the situation Pennsylvania courts countenanced the bailment lease, a device nourished by technical property law." Under such a "lease," the "lessor" delivered possession of the goods involved to the "lessee" upon the latter's promise to pay stipulated "rent" installments, ${ }^{10}$ and at the termination of the lease, the lessee had the option of buying the property for a nominal consideration. The lessor retained the general property interest in the goods, ${ }^{11}$ and under the law of bailments there could be neither effective sale by the lessee nor attachment by his creditors. ${ }^{12}$ The ban against undisclosed liens, which prohibited chattel mortgages and conditional sales, did not taint these transactions because the courts treated them as being what they purported to be, merely rental agreements involving neither sale nor lien. ${ }^{13}$ Clearly the courts were aware of the actual intention of the parties, but the commercial pressure for a valid title-retaining installment sales contract was irresistible.

During the first quarter of this century, the bailment lease was the only valid title-retaining security device, and wide use was made of it by automobile dealers. ${ }^{14}$ In 1925, however, the legislature enacted the Pennsylvania Conditional Sales Act. ${ }^{15}$ Not a complete adoption of the Uniform Conditional Sales Act recommended by the Commissioners on Uniform State Laws, the notable variation of present interest was its failure to assimilate bailment leases to conditional sales. ${ }^{16}$ Since 1925 , then, automobile dealers and finance companies have had a choice of installment sale contracts. Their continued almost exclusive use of the bailment lease has not been due to tradition alone. The protection against the claims of third parties afforded the bailment lessor is not dependent

6. "Security interest" as used in this Note means an interest in property which secures payment or performance of a contractual obligation and is a legal interest as opposed to an equitable interest. For historical treatment of installment sales, see MERLE, INSTAliment Financing IN THE AUtomobILE FIELD (unpublished thesis in $\mathrm{U}$ : of Pa. Library, 1933).

7. See Clow v. Woods, 5 S. \& R. 275, 278 (Pa. 1819).

8. Martin v. Mathiot, 14 S. \& R. 214 ( $\mathrm{Pa} .1826)$.

9. Comment, U. of PiTr. L. REv. 321 (1937).

10. It is fatal for the parties to use words of sale in a bailment lease. The very basis of the validity of this device is the clear language indicating that a mere bailment was intended. Hoeveler-Stutz v. Bodman and Royer, $92 \mathrm{~Pa}$. Super. 425 (1927).

11. Leitch v. Sanford Motor Truck Co., $279 \mathrm{~Pa} .160,123$ At1. 658 (1924) (bailment lessor prevailed over subsequent pledgee) ; see Jacquard Knitting Machine Co. v. Vennell, 59 F.2d 496 (3d Cir. 1932).

12. Crist v. Kleber, $79 \mathrm{~Pa} .290$ (1875); Davis v. Bigler, $62 \mathrm{~Pa} .242$ (1869); Hardy v. Metzgar, 2 Yeates 347 ( $\mathrm{Pa} .1798$ ); Heisley v. Economy Tool Co., $33 \mathrm{~Pa}$. Super. 218 (1907).

13. Dando v. Foulds, $105 \mathrm{~Pa} .74$ (1884); Clark v. Jack, 7 Watts 375 (Pa. 1838); Myers v. Harvey, 2 P. \& W. 478 (Pa. 1831).

14. During the latter part of this period, $65 \%$ of the sales of passenger cars were deferred payment sales. Larson, Financing Automobine Sales 5 (unpublished thesis in U. of Pa. Library, 1922).

15. PA. StAt. AnN., tit. 69, §361 et seq. (Purdon, 1931).

16. Compare $\$ 1$ of the Uniform Conditional Sales Act, with Pa. STat. Ann., tit. $69, \S 361$ (Purdon, 1931). 
upon a public record of the transaction, while such protection is denied the conditional seller who omits properly to file the contract or forgets to refile before the stated time has elapsed. ${ }^{17}$ Furthermore, the seller's rights upon default are more favorable under the common law device, which permits recovery of possession of the motor vehicle and retention of all payments made by the defaulting lessee under usual circumstances. The Conditional Sales Act, on the other hand, makes a resale compulsory if the purchaser has paid over $50 \%$ of the contract price, the proceeds of resale going to the purchaser after subtraction of the seller's expenses and the balance due at the time of the default. ${ }^{18}$

When the inequality of bargaining power in installment sale contracts led to practices on the part of dealers and finance companies which the legislature considered "nefarious, unscrupulous, and improper," 19 the 1947 Motor Vehicle Sales Finance Act was enacted. ${ }^{20}$ This statute brings the activities of dealers and finance companies under close regulation. By its definition of installment sale contracts, ${ }^{21}$ and its introductory section, ${ }^{22}$ the Act purports to establish the positions of the parties in all forms of such contracts. A license is required for all persons engaged in the business of selling or financing automobiles under installment sale contracts. ${ }^{23}$ The Act specifies the form and content of such contracts even to the size of the type to be used in certain portions. ${ }^{24}$ Other sections stipulate permissible finance charges, ${ }^{25}$ prohibit the insertion of some types of acceleration clauses, ${ }^{26}$ give the buyer complete freedom in choosing his insurance broker, ${ }^{27}$ and declare the rights of the parties regarding prepayment, ${ }^{28}$ default, ${ }^{29}$ reinstatement, ${ }^{30}$ and repossession. ${ }^{31}$ But in its failure in important respects to make the rights and liabilities of the parties completely independent of the mere form of security device employed, it has not established a standard installment contract for financing the sale of motor vehicles.

Nothing, for instance, is said about a compulsory resale upon default. By employing the bailment lease, therefore, the dealer apparently can still repossess the car upon default and retain all payments made, thus receiving a windfall which bears no relation to any damages resulting from the purchaser's default. A further shortcoming of the Motor Vehicle Sales Finance Act is its failure to require a public record of all installment sale contracts. Bailment leases, therefore, are still valid against subsequent

17. PA. Stat. Ans., tit. 69, $\S 402$ and 408 (Purdon, 1931).

18. Id., $\$ \S 454$ and 456 .

19. Id., $\$ 602(\mathrm{a})$.

20. Id., $\$ \$ 601-637$.

21. "Installment sale contract . . shall include any loan, any mortgage, any conditional sale contract, any purchase-money chattel mortgage, any hire-purchase agreement or any contract for the bailment or leasing of a motor vehicle under which the hire-purchaser, the bailee or lessee contracts to pay as compensation a sum substantially equivalent to or in excess of the value of the motor vehicle and any other form of contract which has a similar purpose or effect. . . " PA. STAT. ANN., tit. 69, § 603(10) (Purdon, Supp. 1948).
22. Id., $\$ 602$.
23. Id., $\$ 604$.
24. Id., $\$ 613$.
25. Id., \$ 619.
26. Id., \$ 615(B).
27. Id., \$ 617 (B).
28. Id., \$ 622 .
29. Id., $\$ \$ 621,623-627$.
30. Id., \$ 624 .
31. Id., \$ 623 . 
parties without filing or recordation. ${ }^{32}$ A more commercially unsatisfactory and dangerous situation cannot be imagined, for there is no sure way in which even diligent parties can inform themselves of the existence of security interests arising from the use of this device. If the lessee wants to deceive such a party, he may represent that he has clear title to the motor vehicle without jeopardizing the lessor's interest; ${ }^{33}$ and only in early rural communities was the transfer of possession likely to make the bailment lease transaction common knowledge. A mere transfer of possession will almost certainly go unnoticed when the thing transferred is extremely mobile and one of identical thousands. If the bailment lease cannot be banished, then, ${ }^{34}$ it should at least be put on a leash by making its validity subject to some form of recordation to relieve innocent parties subsequently dealing with the motor vehicle from the threat of invisible security interests.

It may be concluded that, although the Motor Vehicle Sales Finance Act has done much to improve conditions, to some extent legal consequences are still made to depend upon the form of security device used.

\section{Liens Arising from Loans: The Motor Vehicle as Collateral SECURITY}

Automobiles are a very great aid in obtaining loans. When a car owner of average income needs cash quickly, very frequently the first thing he offers as security is a lien upon his automobile. Many automobiles, indeed, probably spend their entire lives "in hock." Yet until quite recently, it was impossible for lenders to get practicable, legally protected liens upon motor vehicles in Pennsylvania. The common law pledge does not meet the requisite of practicality since it entails delivery of possession of the car to the pledgee. Few borrowers would forfeit the use of their cars to obtain a loan; they might as well sell them. The conditional sale contract cannot be used because no sale is involved and chattel mortgages were not valid in Pennsylvania until 1945. As a desperate "out," finance companies devised the "bill of sale with bailment lease back." Here the borrower delivers a bill of sale of his car to the lender, and thereupon what purports to be a bailment lease is executed, under which he agrees to make rental payments the total of which equal the amount of the loan plus the company's charge for making it. ${ }^{35}$ Sometimes the automobile is delivered into the possession of the finance company overnight or for a few hours, after execution of the bill of sale and prior to the execution of

32. Grossman v. Land Title Bank \& Tr. Co., 66 D. \& C. 243 (Pa. C.P., Phila. Co. 1948).

33. See Leitch v. Sanford Motor Truck Co., $279 \mathrm{~Pa} .160,164,123$ Atl. 658, 660 (1924) and cases cited there. Where the lessor, however, so clothes the lessee with apparent ownership as to mislead or deceive the public, he may be estopped to deny title in the lessee. Ibid.; Comment, 3 U. of PITT. L. Rev. 321, 331 (1937).

34. The bailment lease furnishes additional revenue for the Commonwealth. Since title remains in the bailor, a foreign corporation doing business in Pennsylvania and buying bailment leases from dealers is subject to a capital stock tax upon the bailed motor vehicles, as well as a mercantile license tax assessed on the volume of business done, including bailment lease transactions. Commonwealth v. Globe Furnishing Co., 324 Pa. 180, 188 Atl. 170 (1936) ; Commonwealth v. Motors Mortgage Corp., $297 \mathrm{~Pa}$. 468, 147 Atl. 98 (1929).

35. Among the numerous cases involving these transactions are: Atlantic Finance Corp. v. Kester, 156 Pa. Super. 128, 39 A.2d 740 (1944); Ambler National Bank v. Maryland Credit Finance Co., 147 Pa. Super. 496, 24 A.2d 123 (1942); Commercial Banking Corp. v. Active Loan Co., 135 Pa. Super. 124, 4 A.2d 616 (1938); Automobile Banking Corp. v. Atlas Automobile Finance Corp., $129 \mathrm{~Pa}$. Super. 501, 195 Atl. 441 (1937). See also Comment, 6 U. of PITT. L. REv. 290 (1940). 
the lease; often there is no delivery at all. This ingenious device for protecting loans by the creation of a security interest in the borrower's motor vehicle soon encountered judicial disapproval. In 1924 the Supreme Court of Pennsylvania observed, "The complicated dealings of those. . loaning money on automobiles have reached a point where the court must strip the transactions of their pretenses and look at them as they really are, . . . the realities of the transactions will be sought by the courts, they will look through the screen of paper titles to ascertain what was the real situation."36 The court was not willing to "strip the transactions of their pretenses" entirely by declaring bailment leases invalid attempts to retain a security interest; it merely looked closely enough to say that these transactions were not bailment leases. The only effect of the bill of sale with bailment lease back, therefore, was to create an unexecuted or equitable pledge, which was ineffective against subsquent parties who obtained possession of the automobile. ${ }^{37}$ There was no valid security interest possible in Pennsylvania without a transfer of possession, and a transfer enduring overnight was no transfer because obviously made in bad faith. ${ }^{38}$ In the face of a great demand, then, the finance companies were left with no safe way of "loaning money on automobiles."

Some protection might appear to have been available to the lender who noted his lien upon the Certificate of Title which had been issued with respect to the automobile involved. Such notation was permitted by a statute in $1923,{ }^{39}$ but no legal effect was given to it. The lender could only hope that he would be able to show that a person claiming to have dealt with the car subsequently in good faith had seen the Certificate of Title, and therefore had actual notice of his interest. A later statute, ${ }^{\mathbf{4 0}}$ providing for delivery of the Certificate to the first lien holder assured protection against subsquent purchasers since there could be no valid sale of a motor vehicle without the transfer of its Certificate of Title. ${ }^{41}$

The real threat to finance companies came from attaching creditors and subsequent pledgees, who did not need to deal with the Certificate of Title. The legislature tried to provide lenders with some protection against these parties. A 1933 amendment to the Vehicle Code made notation "adequate notice to the Commonwealth, creditors and purchasers," and declared that no lien or encumbrance should be invalidated for failure to transfer possession. ${ }^{42}$ We have previously noted that the bill of sale with bailment lease back amounts only to an unexecuted or equitable pledge, ${ }^{43}$ but it can be enforced against subsequent parties having notice of its existence. ${ }^{44}$ In the first judicial interpretation of the amendment, a federal court confirmed the finance companies' belief that they no longer "walked on air" every time they took a security interest in a motor vehicle to

36. Root v. Republic Acceptance Corp., 279 Pa. 55, 57, 129 Atl. 650 (1924).

37. Ambler National Bank v. Maryland Credit Finance Co, $147 \mathrm{~Pa}$. Super. 496, 24 A.2d 123 (1942) (as between two equitable pledgees, the first to gain possession of the vehicle acquires the superior lien).

38. Automobile Banking Corp. v. Atlas Automobile Finance Corp., 129 Pa. Super. 501, 195 Atl. 441 (1937).

39. Act of May 24, 1923, P.L. 425.

40. Act of April 27, 1925, P.I. 286.

41. Stonebraker v. Zullinger, 139 Pa. Super. 134, 11 A.2d 698 (1939) ; Comment, S U. of Pitt. L. Rev. 48 (1941).

42. Pa. Stat. AnN., tit. 75, §38 (Purdon, Supp. 1948).

43. See note 36 supra.

44. Newman v. Globe Indemnity Co., 275 Pa. 374, 119 Atl. 488 (1923) ; Davis v. Billings, 254 Pa. 574, 99 At1. 163 (1916). 
safeguard a loan to its owner. ${ }^{45}$ Soon, however, the bubble burst and they were back to their insecure footing. The amended section of the Vehicle Code had been entitled "Transfer of ownership by operation of law or judicial sale." In Kanfmann and Baer v. Monroe Motor Line, ${ }^{46}$ where Pennsylvania creditors of a New York firm seized two trucks on which chattel mortgages, noted upon a Pennsylvania Certificate of Title, had been given to another New York firm, the chattel mortgagee argued that, under the amendment to the Vehicle Code, these creditors had notice of its liens. The Superior Court held, however, that the amendment applied only where the automobile was in the possession of one who had received it by operation of law, e. g., by replevin, order in bankruptcy, or inheritance. Since only a relatively infinitesimal number of motor vehicles are so transferred, this interpretation made the amendment unimportant.

The Vehicle Code was amended again in 1939 and this time the same provision was put into a section which applied to all transfers. ${ }^{47}$ There has not yet been a decisive judicial interpretation of the 1939 amendment. Some trial courts have refused to give it any effect; ${ }^{48}$ others have decided that noted liens can be asserted against subsequent parties even though there has been no transfer of possession. ${ }^{49}$ The Circuit Court of Appeals for the Third Circuit has agreed with the latter interpretation. 50 In the few cases which have come before the Superior Court, the court has not determined the effect of the amendment beyond deciding that it does not give the lender the right to replevy an automobile seized by a creditor of the borrower, where there had been no default. ${ }^{51}$

Belatedly, in 1945, the Chattel Mortgage Act was passed. ${ }^{52}$ Finally finance companies could feel certain of their safety in granting car loans: the Act specifically refers to motor vehicles. ${ }^{53}$ An important ambiguity should be noted. Although a general section of the Act provides that all chattel mortgages shall take effect and be valid against the rights of subsequent parties from the time they are filed, ${ }^{54}$ Section 5 requires that all mortgages on motor vehicles be noted on the Certificate of Title. ${ }^{55}$ Lenders are left with the problem of deciding whether compliance with both

45. In In re Fell, 16 F. Supp. 987 (E.D. Pa. 1936), the court held that notation of an unexecuted pledge would give subsequent purchasers and creditors notice of its existence and prevent them from acquiring an interest in the motor vehicle superior to that of the equitable pledgee. But see note 46 infra.

46. $124 \mathrm{~Pa}$. Super. 27, 187 At1. 296 (1936). This case caused the overruling of In re Fell, note 45 supra, by the Third Circuit in Taplinger v. Northwestern National Bank, 101 F.2d 274 (3d Cir. 1938).

47. Pa. Stat. ANN., tit. 75, §33 (Purdon, Supp. 1948), entitled "Contents, delivery, effect, and life of certificate of title." (emphasis added). Inclusion of the provision in this section, applying to all transfers, made its inclusion in $\$ 38$, which applied to transfers by operation of law, superfluous.

48. Morse v. Phillips, 44 D. \& C. 289 (Pa. C.P., Erie Co. 1942) (characterizing it as "meaningless"): Personal Finance Co. v. Cohen, 43 D. \& C. 215 (Pa. C.P., Wash. Co. 1941); Hayward v. Wandrie, 21 Erie Co. L.J. 258 (Pa. C.P. 1940).

49. Ewing v. Meehan, 41 D. \& C. 689 (Pa. C.P., Beaver Co. 1942) ; Pottstown Finance Co. v. Ibach, 58 Montg. Co. L. Rep. 223 (Pa. C.P. 1942).

50. In re Berlin. 147 F.2d 491 (3d Cir. 1943) ; In the Matter of Beyer and Co., Inc., in Bankruptcy, Cause No. 21, 385 (E.D. Pa., January 3, 1941) (unreported).

51. Atlantic Finance Corp. v. Kester, $156 \mathrm{~Pa}$. Super. 128, 39 A.2d 740 (1944). In Ambler National Bank v. Maryland Credit Finance Co., $147 \mathrm{~Pa}$. Super. 496, 24 A.2d 496 (1942), although the 1939 amendment to the Vehicle Code was held inapplicable, the Superior Court intimated that perhaps under that Act liens noted on the Certificate of Title might be valid without a transfer of possession.

52. PA. Stat. ANN., tit. 21, \$\$940.1-940.16 (Purdon, Supp. 1948).

53. Id., \$ 940.5 .

54. Id., \& 940.8 .

55. Id., § 940.5 . 
sections is necessary to create an unassailable security interest. ${ }^{56}$ This uncertainty calls for corrective legislation. The need for such legislation is brought into sharper focus when the situation which obtains with regard to conditional sale contracts is considered. If any record of bailment leases or chattel mortgages upon a motor vehicle exists, it will appear on the Certificate of Title. A private party, therefore, purchasing a used automobile, or lending money on it, could reasonably fail to look elsewhere, expecting that liens arising from conditional sale contracts would likewise appear there. ${ }^{57}$ But the Pennsylvania Conditional Sales Act protects sellers who have properly filed their contracts and does not require notation of conditional sales of automobiles. ${ }^{58}$ The danger to the average purchaser who may rely on the Certificate of Title for a full disclosure of existing security interests is evident. The objection to the present situation, therefore, is not based merely upon statutory obscurity as to the proper method of giving notice of existing chattel mortgages, but also upon the more urgent ground that even reasonably careful persons may be misled and injured by the uncorrelated provisions of the various statutes.

\section{Suggested Statutory Amendments}

Virtually all difficulties concerning motor vehicle liens arise from the variety of security devices, each having its own characteristic incidents, which may be used. ${ }^{59}$ Whether any record of the security interest is required, how such record must be made, and, to some extent, what rights the parties have upon default, are all questions whose answers depend on the device employed. Yet the problems underlying all security transactions involving motor vehicles are the same. The Pennsylvania legislature apparently recognized this fact when it passed the Motor Vehicle Sales Finance Act, which applied without regard to the form of the transaction. This statute's incompleteness has been pointed out in the preceding discussion. Changes in the Act and the Vehicle Code along the lines of the amendments suggested here might provide the desired uniformity.

Notation of Security Interests. - The threat to innocent parties inherent in the valid unrecorded bailment lease is very serious. This creation of the common law has outlived the situation which brought it into existence; the very courts who were responsible for its birth recognize this. ${ }^{60}$ It exists as a dangerous anomaly in a community which has learned to depend upon recording acts for safety. To provide diligent persons with the means to protect themselves, there should be a record of all security interests in motor vehicles.

56. Another problem was formerly thought to exist regarding notation of chattel mortgages on motor vehicles. It was feared that the Secretary of Revenue might not be authorized to issue Certificates of Title except upon a transfer of possession or satisfaction of a previously existing lien. This would impede notation of mortgages in loan transactions unless some fictitious transfer could be effected. However, the Bureau of Motor Vehicles now uses Form RVT-33a, "Application for Duplicate Certificate of Title, for Recording Encumbrances After Title has been Issued," indicating that there is no longer any necessity of an assignment and reassignment of the owner's Certificate. Letter to the REvIEw from the Bureau of Motor Vehicles, Harrisburg, Pa., dated December 14, 1949.

57. Byse, Automobiles-Recording of Encumbrances-Certificate of Title, 12 WIS. L. REV. 92, 93, 94 (1938).

58. Pa. Stat. ANn., tit. 69, § 401 (Purdon, 1931).

59. Leary, Our Uncorrelated Chattel Security Law, 19 PA. B.A.Q. 295 (1948).

60. Comment, 3 U. of PitT. L. Rev. 321 (1937). 
The Certificate of Title is uniquely fitted to serve as a recording device. There is one outstanding with respect to every motor vehicle owned in Pennsylvania, ${ }^{61}$ and although the courts held for years that it was not a muniment of title, ${ }^{62}$ there can be no valid sale without its transfer. ${ }^{68}$ It is easy to see, therefore, that were all security interests noted upon the Certificate of Title, the ascertainment of the condition of the title to any motor vehicle would be simplified. There would no longer be any necessity for a search through voluminous records in local offices. Furthermore, the Vehicle Code permits an uncomplicated procedure for notation of liens. ${ }^{64}$ For these reasons it is suggested that the Code be amended so as to make notation the exclusive method of giving notice of security interests in motor vehicles. Clearer and more satisfactory legislation will result if reference is made to other statutes affected. It is proposed, therefore, that Section 33 of the Vehicle Code be amended as follows:

\section{“33. Contents, Delivery, Effect and Life of Certificate of TiteE.}

“

"(b) . . . The certificate of title, when issued by the secretary showing a lien or encumbrance, shall be adequate notice to the Commonwealth, [creditors, and purchasers] and to subsequent parties without actual notice dealing with the motor vehicle, trailer, or semitrailer, or acquiring an interest therein that a lien against the motor vehicle, trailer, or semi-trailer exists, and failure to transfer possession of the vehicle, trailer, or semi-trailer shall not invalidate said lien or encumbrance." Any lien or encumbrance shall be void and of no effect against subsequent parties without actual notice dealing with said vehicle, trailer, or semi-trailer or acquiring an interest therein, unless and until application has been made for a certificate of title showing said lien or encumbrance, and application for a certificate of title showing said lien or encumbrance upon said vehicle, trailer, or semitrailer shall make unnecessary and be in lieu of compliance with the provisions of any other act, including section five of the Act of June first, one thousand nine hundred and forty-five (Pamphlet Laws $1385)^{65}$ and section six of the Act of May twelfth, one thousand nine hundred and twenty-five (Pamphlet Laws 603), ${ }^{60}$ which otherwise would require filing or recordation of said lien or encumbrance. ${ }^{\text {or }}$

61. Pa. Stat. AnN., tit. 75, §31 (a) (Purdon, Supp. 1948).

62. Braham \& Co. v. Stienard Hannon Motor Co., 94 Pa. Super. 19 (1929). This case has been frequently cited as authority for holdings that the Certificate of Title was merely evidence of ownership.

63. See note 41 supra.

64. See note 56 supra.

65. Section 5 of the Chattel Mortgage Act, Pa. Stat. Ans., tit. 21, $\$ 940.5$ (Purdon, Supp. 1948).

66. Section 6 of the Conditional Sales Act, Pa. Stat. ANn., tit. 69, §403 (Purdon, 1931), as amended, PA. Stat. ANN., tit. 69, $\$ 403$ (Purdon, Supp. 1948).

67. Italics indicate suggested amendment; bracketed material to be deleted from present statute. Even a statute providing for central recordation of motor vehicle liens and notation of such liens does not establish a foolproof method of handling these liens. An owner might still be able to take advantage of innocent parties. If he executes a chattel mortgage in favor of $A$ and delivers his Certificate of Title to $A$ to record the security interest, and immediately goes to $B$, representing that his car is so new or a used car so new to him that his Certificate of Title has not yet been delivered, there is no sure way in which $B$ can learn of $A^{\prime} s$ prior interest. If he contacts the central recording office, he will be told that the motor vehicle had a clear 
Final Establishment of the Rights of Parties upon Default.-There is no apparent reason why the remedies and liabilities of parties to a security transaction involving motor vehicles should depend upon the formal attributes of the security device used. In every such transaction, the fundamental problem is to give effective protection to the interest of the seller or lender, without prejudice to the rights of the car owner. In the Motor Vehicle Sales Finance Act, the Pennsylvania legislature has attempted an answer, with regard to installment sales, by setting out a number of the rights of parties to these contracts, including rights for the duration of the contract and rights upon its termination by performance or default. But the legislature has failed to consider all the consequences of factual situations which may arise, and has consequently not explicitly declared all rights. Rights still differ according to the type of installment sale contract employed; the buyer's right of compulsory resale upon default, for example, is not mentioned in the Motor Vehicle Sales Finance Act, and is, therefore, secured only to conditional vendees. Because all security transactions are intended to be regulated by the Act, the legislature should consider its position on every legal consequence which presently differs according to the mere form of security device used, ${ }^{68}$ and express that position statutorily by amendments to the Motor Vehicle Sales Finance Act.

Although amendment of the Motor Vehicle Sales Finance Act may finally stabilize the law of installment sale of motor vehicles, it will have no effect upon loan transactions. But since the chattel mortgage, far superior for most loans, is now available in Pennsylvania, the difficulties incident to a multiplicity of available security devices need not arise here. ${ }^{68}$

\section{The Ever-Existing Interstate Problem}

Although the proper subject of this Note is confined to motor vehicles lien law in Pennsylvania, mention must be made of the laws in other states. For automobiles, unlike most other widely owned chattels, are designed to move. Their location can be changed from one part of the nation to another speedily and easily; thousands cross state lines each day. Therefore, diversity between the motor vehicle laws of the various jurisdictions constitutes a potential booby-trap to be sprung upon any one buying, selling, or financing automobiles. ${ }^{70}$

An illustration of the difficulties which arise from the present lack of coordination between vehicle laws is presented by the Pennsylvania decisions on the effect of foreign chattel mortgages. It is almost universally

title since $A$ 's application for a Certificate of Title showing his lien would not yet have reached the office. But since $B$ can adequately protect himself by waiting a day or two after a prospective borrower has come to him for a loan before ascertaining the condition of the title, and since he should be aware that any very new car is likely to be subject to an outstanding security interest, the first lender should be protected by making his interest fully effective from the time of application for a Certificate of Title showing his lien or encumbrance.

68. E.g., the criminal sanctions imposed upon an installment buyer for conversion of the goods without permission of the seller. For a full discussion of these penalties, see Note, Criminal Sanctions Protecting the Credit Seller, 98 U. of PA. L. REv. 230, 239 (1949).

69. Should lenders fail to use the chattel mortgage exclusively, a statute similar to the Motor Vehicle Sales Finance Act may become necessary to clarify the situation. The bill of sale with bailment lease back, where it can be asserted against subsequent parties, gives the lender the rights of a pledgee, not those of a bailment lessor.

70. See Leary, Horse and Buggy Lien Law and Migratory Automobiles, $96 \mathrm{U}$. of

PA. L. REv. 455 (1948) for a full discussion of the problems which can arise here. 
held that a chattel mortgage validly created will be recognized as against third parties by the courts of any other state to which the chattel is removed without the consent of the mortgagee. ${ }^{71}$ For many years, however, Pennsylvania refused to follow this rule on the ground that "it had been the settled public policy of the law of this Commonwealth as manifested by legislative acts and judicial decisions, to frown upon the mortgaging of chattels in Pennsylvania." 72 The enactment of the Chattel Mortgage Act in 1945, validating chattel mortgages in Pennsylvania, might have changed this, ${ }^{73}$ but in First National Bank of Jamestown $v$. Sheldon, ${ }^{74}$ the Superior Court held that the time-honored Pennsylvania rule still applies to foreign chattel mortgages on automobiles, since Section five of the Act requires notation on a Pennsylvania Certificate of Title as a condition precedent to the validity of motor vehicle mortgages. Thus it would appear that a chattel mortgagee is unprotected if the automobile subject to his security interest is brought into Pennsylvania without his consent and sold to an innocent purchaser.

Apparently the only comprehensive remedy to the muddle produced by the existence of different lien laws in the forty-nine jurisdictions is a Uniform Motor Vehicle Lien Act. Such a statute would give purchasers and financers an opportunity to protect themselves regardless of state lines. Originally the proposed Uniform Commercial Code contained a Part on vehicle liens for this purpose, ${ }^{75}$ but it has been omitted from a later draft.76 Pennsylvania has so substantially modernized its motor vehicle lien law in recent years, that one may now hope for its acceptance of a Uniform Act.

J.F.E. G.

71. 2 Beate, Confltct of Laws $\$ 268.1,275.1$ (1935); Lee. Conflict of Lawes Relating to Installment Sales, 41 MicH. L. REv. 445, 448, 452 (1942).

72. First National Bank of Jamestown v. Sheldon, 161 Pa. Super. 265, 268, 54 A.2d 61, 62 (1947).

73. The reason for the Pennsylvania rule seems to have been the fear that recognition of the rights of foreign chattel mortgagees would have given them an advantage over Pennsylvania lenders. See Morse v. Phillips, 44 D. \& C. 146, 148 (Pa. C.P., Erie Co. 1942).

74. 161 Pa. Super. 265, 54 A.2d 61 (1947).

75. Uniform Commercial Code, Art. 7, Pt. 8 (May, 1949 Draft).

76. See Minutes of Meeting of July 25, 1949 of the American Law Institute. 